\title{
Socio-Philosophical Essence of the Concept of "Modern Person"
}

\section{Olimova ${ }^{1}$}

${ }^{1}$ Senior Lecturer of Gulistan State University

\begin{abstract}
:
The article explores the socio-philosophical role of the individual in nature and society, human qualities and intellectual characteristics.
\end{abstract}

Key words: Man, personality, social development, intellectual potential, spiritual reforms, changes in thinking and field of activity.

Article Received: 16th October, 2020; Article Revised: 30th December, 2020; Article Accepted: 08th January, 2021

The socio-philosophical essence of the concept of modern personality. The specific features of the socio-philosophical formation and the influence of the macro and micro environment in which it lives are taken into account. If a person explains the sources of social activity, he explores the laws and ways in which social activity manifests itself. Explains the social nature of interpersonal relationships within different human groups. I am interested in how social relations are manifested in the activities of each individual and in certain groups, and their influence on the formation of personality traits.

Social communities are armed with scientific methods of analyzing interpersonal relationships in them, thereby helping to solve the most important problem of forming a new person. Also, as in any field, social learning begins with general learning, because it is impossible to consider the problems that need to be solved socially without a deep knowledge of the general laws, the basic concepts.

First, its main focus is the study of small groups and communities. Each person always operates within certain social groups. This includes his family, work team, circle of friends in an informal group on the street, study group, and so on. A number of phenomena, such as individual and group behavior, behavior, position, group influences, interpersonal

compatibility in the group, leadership, vulnerability to group pressure, in fact, the management of those groups, the creation of conditions for interaction - this is the need to teach people effective communication . Interaction between people in groups, ways of interacting with each other, teaching people to communicate effectively is also a social function of groups.

Second, the social study of the individual. The issue of the social image of the individual is also a very important area in today's era of change and spiritual purification. When considering the sociophilosophical essence of the individual as an object of study, first of all, his behavior, social motives, his orientation, norms of behavior, various social roles of the individual in society, position, factors of social integration-socialization; selfesteem, attitudes, respect of the person and influence of social, historical and cultural conditions on the consciousness of the person, types of the person are studied.

Third, Mass socio-philosophical events Mass events that occur at the level of society have a social practical significance, because the denial of the influence of mass 
events, large groups in the upbringing of the individual is tantamount to a one-sided approach to the issue. For example, for a person, the psyche of the nation, people or people to which he belongs, the traditions, customs, beliefs, customs, activities that have been preserved in his mind for centuries, have a certain influence.

Fourth, the family as an object of social learning. Here the family-specific processes, the relationship of family members to each other, issues of compatibility in marriage, the factors of family conflicts, socio-philosophical methods of raising children in the family are studied.

Another task is to find scientifically based answers to the questions of what happens in the minds of everyone during the period of dramatic changes, how he perceives these changes, how to activate his vital position in a purposeful way, in collaboration with other relevant sectors. .

One of the most fundamental and socially studied issues, including the problems mentioned above, is this behavior. According to scholars, today is both a socio-philosophical subject and a common object of all research conducted within it. Determining its place in human life is one of the most important areas of applied science, highlighting the types and methods of behavior that are effective in the context of various social activities, the study of its pure mechanisms. Therefore, the study of factors that increase the effectiveness of interpersonal communication in each specific situation is one of the important problems of the modern concept of personality.

The formation of personality is carried out mainly in three areas:

1) the field of activity, ie during the life of the person is directly or indirectly involved in various activities, in the process of which the field of activity expands and becomes richer. Each type of activity requires from the individual special qualities, skills and abilities, knowledge, the activity of which in the way of their satisfaction forms in him a complex of specific socio-psychological features;

2) the field of communication, especially in preschool and adolescence, communication develops in the child a number of social traits, as a result of which he acquires an active life position, achieves an idea of his place in society.

3 ) the field of self-awareness, ie the process of changing the image of "I" from year to year, first realizing that he is different from others, the ability to act independently, to think independently, and then self-assessment, understanding, control - features develops that they are also part of the active person.

There are these stages of a person's socialization. For example, the first stage is the pre-employment stage, which includes the child's pre-school age and school years. The importance and specificity of socialization in this period is that in this period, mainly the external social environment, social influences are actively absorbed into the consciousness, an important stage in the preparation for independent living. The second stage - the period of labor activity - this period is associated with the years of human maturity, which reflects the social influences absorbed in previous periods directly in active activity, in the system of interpersonal relationships. All the social qualities that are manifested in a person who has a profession, chooses a clear way of life, gets married and raises the next generation is the product of this period. Finally, the third stage is the post-labor period, which mainly includes those who are aging after active labor activity. During this period, the socialization of the individual continues, because now the experience gained in previous periods is transferred to others, and accordingly, there are special changes in the structure of the individual.

When we talk about the conditions under which this process takes place institutions, we mean the role of the family, children's institutions, schools, 
other institutions, labor collectives at different times. They sought to find the causes of a person's social qualities by explaining behaviors in different social contexts. Every person is always present in the system of social interaction, in which he must try to understand others, be ready to accept the role of others in order to act correctly. But in order to properly accept the role of others, it must have a "generalized other" image, which is formed in the process of interpersonal communication, in the process of communicating with a group of people who are exemplary for each person. .

The concept of the modern person In the late 19th and early 20th centuries, three theories emerged in science that rightly contributed to the formation of the sociophilosophical essence as an independent scientific direction. What unites these three theories is that each of them independently considered the scientific explanation of the relationship between the individual and society to be the main theme of the research. Some individuals become parts of that wholeness. That is, the problem of conflict between the individual and society is resolved in favor of society. Gegel's philosophy and German Romanticism served as the historical and ideological basis of this theory.

So, the significance of the three theories mentioned above was that they revealed the subject of the new science to be born the socio-philosophical. In addition, all three directions have shown the need to use experiment, which is a method of objective verification, in proving theoretical views. This thing once again helped to determine the future plans of a particular science. All conscious and unconscious processes are expressed in external behaviors, actions, so it is possible to study the person himself and the reasons for these actions by studying external actions, gestures, speech, sound. Therefore, there is confusion in defining the universal laws of development of the individual and society.
In the 1920s and 1930s, two directions emerged to study the social development of children and adolescents, which also failed to avoid a number of shortcomings.

There are very important research topics in Uzbekistan, which should develop the basis of scientific management of social behavior, the changes in the individual and various social groups in the current conditions of independence, the social perceptions of people belonging to different age, demographic and ethnic groups. That is, the social management of production is waiting for its solution, in which the national peculiarities of the region should be developed using the achievements of advanced science.

Such people cannot destroy an organized society with false beliefs, shouts, and slogans. Such a society is ideologically and politically stable, in which justice takes precedence. Independent, freethinking individuals cannot be distracted from the life goals they have chosen by the intellect and the heart.

In recent years, thanks to independence, the sacred task of every person, every family, our society is to raise talented children, to bring them up physically and spiritually, to bring them up as loyal to their parents and homeland. That is why in the Constitution of independent Uzbekistan the main link of the family and society, motherhood and childhood are protected by the state. It has been stated that adult, able-bodied children are obliged to take care of their parents. In these reliable legal guarantees lie the immortal heritage of the long and bright historical path traversed by our people. After all, kindness and respect for parents and each other have been passed down from generation to generation for centuries.

It is no coincidence that in our country the main task is to form the spiritual image of young people on the basis of the ideology of independence, its human principles. 
Because the three pillars of our independence - independent politics, economic power and the spirituality of the people are closely linked, and only if their harmonious development is ensured, Uzbekistan as a great country will be able to take its rightful place in the world community. The national customs, traditions, values of the Uzbek family, the teachings of our ancestors on the upbringing of children are extremely exemplary. A simple example: In most Uzbek families, the upbringing of grandparents with great life experience, respect and care for the little ones, and the sacred knowledge of the parents are common qualities. high respect has been preserved.

The family is an important part of the spiritual and physical formation of young people. It is in the family that high-level moral and spiritual qualities such as mutual respect, kindness, honesty, diligence, humanity and patriotism are formed and passed down from generation to generation.

From the first days of independence of our country, priority has been given to the care of young people and their future. After all, the democratization of our society was based on the goals of civil society, in fact, the interests of the people, the youth, who are the backbone of our country, our development.

It is known that one of the first laws adopted shortly after the declaration of independence of our country was dedicated to the issue of youth. In November 1991, the Law of the Republic of Uzbekistan "On the Fundamentals of State Youth Policy in the Republic of Uzbekistan" was adopted. This law, while guaranteeing the comprehensive rights of the youth of our country in the political, social and spiritual spheres of society, has established the initial and decisive legal basis for the upbringing of a harmoniously developed generation. In particular, the first article of the law states that "Youth policy is a priority of the state activity of the Republic of Uzbekistan, the purpose of which is to create socio-economic, legal and organizational conditions for the social formation and development of youth, their creative potential in the public interest. and guaranteeing them."

It was not in vain that such an urgent task was put on the agenda. Even in the first years of independence, the old way of thinking, the knowledge left behind in world development, the views that have lost their value were preserved in the worldview of young people. For example, until recently, the task of higher education was to train specialists with a certain amount of scientific and technical knowledge, who inculcated ideological guidance in their minds.

Naturally, such a situation required the formation of a harmonious spirituality in the youth, worthy of the new age. The main direction of the measures taken in the country in this regard was the humanization of education. An important step in this direction was the Decree of the President of the Republic of Uzbekistan dated September 17, 1991 "On the exclusion of public authorities and administration, as well as the public education system from the party." The Decree states: "It should be noted that the formation of organizational structures of political parties and movements in the state apparatus of the republic and in the public education system is no longer allowed." The conclusion of the decree was that in the sense of bringing education and public education closer to world practice, it was to free it from the ideological influence that served to justify the path of the ideas of the ruling party. Indeed, a new approach has emerged in the republic to the role and place of the social sciences in the higher education system, which is a source of theoretical and scientific knowledge for the ideology of the former Communist Party. For example, in order to implement 
the Law of the Republic of Uzbekistan "On Education", the Ministry of Higher and Secondary Special Education has developed the "Higher Education Reform" Program. An important principle of this Program was the humanization of higher education. In particular, the program is "an integral part of training specialists in the field of humanitarian education and is based on strengthening and developing the spiritual heritage of the Uzbek people, fostering commitment to universal values, citizenship and patriotism, humanism, which is the basis of the national spirit of the Uzbek people."

Of course, educating young people in a way that is worthy of a renewed democratic, humane society, in turn, requires the provision of social guarantees. In this regard, after the independence of Uzbekistan, the development of youth policy aimed at creating conditions for social security of young people in the country has become important. For example, at the session of the Supreme Council of the Republic of Uzbekistan on November 20, 1991, the Law "On the Foundations of State Youth Policy in the Republic of Uzbekistan" was adopted. This law defines the purpose of the state youth policy: "Youth policy is a priority of the state activity of the Republic of Uzbekistan, the purpose of which is to ensure the social formation and development of young people, the full realization of their social potential in the public interest. to create conditions and guarantee them. "The document also provides for organizational measures for the implementation of state youth policy. The law came into force on January 1, 1992. Enterprises, institutions and organizations have identified specific practical measures in this regard. Great attention was paid to the implementation of the law in the country.

In a country of young people like Uzbekistan, the fact that youth policy is considered a great confidence in them shows that there is a high level of confidence in the future of the nation.

It is known that in the process of building a new society, the high responsibility of the members of the society to maintain stability in social relations, a high level of cultural attitude to the tasks ahead, will be as necessary as water and air. Achieving such an effect is, of course, directly related to the task of forming a high spirituality. Therefore, the task of building a new democratic society in our country is determined by the development of the spiritual foundations of our society. After all, the basis of the goal of development of our country is the realization of the human factor and its interests.

As the head of our state said: "We must all know a deep truth - no matter how wellthought-out program we create for the future development of our country, no matter what material base and opportunities we create to achieve these levels, no matter how much investment we mobilize. There is one factor, and that is that we have a highly qualified workforce and mature young people who are able to take responsibility for the development of our country tomorrow, I think it would not be a mistake."

As a practical result of the educational work carried out in the spirit of patriotism, the heroic deeds of the young men of our country in the military field can be clearly demonstrated.

At the present time, when the processes of globalization are deepening, we must not forget that the task of further improving the patriotic education of the youth of our society and achieving effective practical results is becoming increasingly important. After all, international globalization is an extremely complex and multifaceted process, and not all nations have the same influence on the fate of nations. Therefore, the role of patriotism in the strengthening of national 
independence of our country, the formation of strong immunity to the negative effects of globalization is immeasurable.

The human problem is one of the age-old problems of philosophy. The question of how human life should be organized a hundred years ago is on the agenda. The achievements of research based on the principles of history, cultural anthropology, and evolutionism deal a severe blow to the traditional approach to the human problem. The fact that the idea of human nature has been used to justify many injustices and atrocities in human history also has an impact on this. Numerous studies and destructive experiments on the creation of a "new man" by various political, ideological and other means have shown in practice that man is not an object or a means of achieving goals beyond himself. In today's industrial society, where nature is exploited to an unprecedented extent, the concept of human nature becomes particularly complex. In such a society (and the emerging postindustrial society) man feels like a toy in the hands of certain forces. All this leads to an increase in man's interest in himself, an increase in attention to human nature. As a result, the human sciences are developing rapidly today. This process also applies to the science of philosophy, and in each period of historical development, the approach to the human problem has been considered and studied through new aspects, prisms.

The modern man and his modern image represent the place and activity of the modern man in the life of society. In this sense, the modern man is a state of mind, a way of life, a composition of thoughts. This is achieved through constant learning, self-engagement. In the renewal of society, in the transformation of its spheres in accordance with the requirements of the times, of course, the interpretations of modernity have a place in the national identity.
The national consciousness, national pride and national pride of our people are growing and their spiritual world is getting richer day by day. This creates an opportunity to further strengthen the spiritual and ideological basis of our independent state.

But it cannot be concluded that there is no problem with this. Today, at a time when Uzbekistan has gained state independence and created the socio-economic and spiritual intellectual basis for building a new society, there are socio-political and spiritual-ideological factors that seriously affect the formation of independent thinking. The formation of independent and free thinking, especially among young people, is becoming an urgent task. This issue requires a new approach.

This means that if young people do not have their own independent thinking, a culture of independent thinking, it will be difficult for them to withstand the pressure of foreign and hostile ideas, both overt and covert.

Now, especially in the works of the head of our state, the phrase "independent thinker" is often used. So what is meant by "independent thinking free person"? As the President noted in his book "I believe in the strong will of our wise people," it is "a man of self-respect, strong-willed and faithful." he is a man who has a definite purpose in life." Elsewhere in the work, the concept is described in more detail: "He is a man of his own mind, thinking, responsible, conscious, free and free-thinking." 1

Such people cannot destroy an organized society with false beliefs, shouts, and slogans. Such a society is ideologically and politically stable, in which justice takes precedence. Independent, freethinking individuals cannot be distracted 
from the life goals they have chosen by the intellect and the heart.

Our national idea can be the main "mechanism" of Uzbekistan in the successful implementation of reforms in the XXI century, ensuring stability in society and entering the system of world values.

\section{REFERENCES:}

[1] Mirziyoev Sh. M. Decree "On the Action Strategy for the further development of the Republic of Uzbekistan" 07-02-2017. "Khalq so'zi" newspaper.

[2] Mirziyoev Sh. M. We will build our great future together with our brave and noble people.-T, 2017.

[3] Karimov. High spirituality is invincible.-T, 2008.

[4] Tulenov J. Philosophical culture and spiritual maturity - Tashkent, "Labor", 2000.

[5] Robert S. Feldman, Steven S. Schwartzberg thinking critically: a psychology student's guide. McGraw - Hill, Inc 1990.

[6] Ronaldson T. Issues in Moral philosophy - McGraw - Hill, Inc. New York, 1986 